\title{
Suorakylvön ajoitus ja työsyvyys määräytyy savimaan kosteuden mukaan
}

\author{
Laura Alakukku \\ Maa- ja elintarviketalouden tutkimuskeskus, Maaperä ja ympäristö, 31600 Jokioinen, \\ laura.alakukku@mtt.fi
}

Suorakylvössä kasvusto perustetaan esikasvin jälkeen muokkaamattomaan maahan. Lähtötilanne on erilainen kuin perusmuokatussa maassa. Muokkaus nopeuttaa pintamaan kuivumista ja lämpenemistä. Muokattu maa on myös löyhää sänkimaahan verrattuna. Kevätviljan suorakylvöstä tehtiin esikokeita savimaalla 1990-luvun alussa. Tulokset eivät olleet rohkaisevia. Suorakylvetyn koetekijän sato oli jopa $25 \%$ pienempi kuin tavanomaisesti muokatun koetekijän (Alakukku julkaisematon aineisto). Suorakylvökoneen vantaat eivät peittäneet siemeniä riittävästi, mikä haittasi siemenen itämistä ja kasvuston orastumista. Siemen ja savimaan välinen kontakti oli huono ja vantaiden muokkaama haihtumissuoja ei ollut riittävä kosteuden säilymiseksi siemenen ympäristössä. Tässä tutkimuksessa selvitetään kevätviljan (ohra, (Hordeum vulgare), kaura (Avena sativa) ) alkukehitystä suorakylvettäessä. Suorakylvettyä kasvualustaa verrataan kynnetyn ja sänkimuokatun savimaan kylvöalustaan. Tutkimuksen tavoite on kehittää menetelmää ja siten varmistaa kevätviljojen nopea ja tasainen alkukehitys savimaan suorakylvössä. Esityksessä käsitellään neljän ensimmäisen koevuoden tuloksia kahdelta savimaan koekentältä.

Kenttäkokeet perustettiin Jokioisiin hiuesavimaalle (Vertic Cambisol, vuonna 2000) ja hiesusavimaalle (Eutric Cambisol, 2001). Muokkauskerroksessa $(0-20 \mathrm{~cm})$ hiuesaven savespitoisuus oli $590 \mathrm{~g} \mathrm{~kg}^{-1}$ ja hiesusaven $460 \mathrm{~g} \mathrm{~kg}^{-1}$. Hiuesavimaan kentällä pääruudun tekijä oli syysmuokkaus: (P) kyntö 20-25 cm syvyyteen, (S) sänkimuokkaus $(10-15 \mathrm{~cm})$ ja $(\mathrm{N})$ ei perusmuokkausta (sänki). Keväällä osaruutukäsittelyt olivat: (A) jyrsinkylvö (siemenrivien väli $125 \mathrm{~mm}$ ), (B) kylvö suorakylvökoneella (siemen (riviväli $125 \mathrm{~mm}$ ) ja lannoite sijoitettiin eri riveihin ja (C) kylvö suorakylvökoneella (siemen ja lannoite kylvettiin samaan riviin, riviväli $140 \mathrm{~mm}$. Perusmuokatut ruudut tasausäestettiin ennen kylvö. Hiuesavimaan kokeessa koetekijät olivat: PA, SA ja NC. Siemenja lannoitemäärä oli sama kaikissa koetekijöissä. Typpilannoitus oli 90-100 $\mathrm{kg} \mathrm{ha}^{-1}$.

Vuodesta 2001 alkaen kylvön yhteydessä määritettiin maan kosteus kerroksittain ja siemenen ympärillä, maan lämpötila kylvösyvyydessä, kylvöalustan murujakauma ja kylvösyvyys. Kasvukauden aikana määritettiin maan kosteus ja kasvuston kehitys viikoittain. Syksyllä määritettiin siemensato ja siinä korjattu typpisato sekä puintikosteus.

Tulosten mukaan kylvön ajoitus ja kylvösyvyys vaikuttivat merkittävästi kevätviljan kylvön onnistumiseen ja sitä kautta kasvuston alkukehitykseen. Vuosina 2000-2002 muokatun maan tasausäestys vähensi evaporaatiota siinä määrin että kaikki koetekijät voitiin kylvää samana päivänä. Tästä huolimatta suorakylvetty maa oli $0-15 \mathrm{~cm}: n$ syvyydessä märempää kuin syysmuokattu maa. Vuonna 2003 suorakylvetyt ruudut kylvettiin 1-3 viikkoa myöhemmin kuin syysmuokatut ruudut, koska muokkaamaton maa kuivui hitaasti sateisena keväänä. Myös tänä vuonna suorakylvetty maa oli kylvöaikaan kosteampaa kuin muokattu. Vuosian 2000-01 kaikki koetekijät kylvettiin samaan syvyyteen ja kylvö ajoitettiin muokatun maan kosteuden mukaan. Tällöin siemen ei peittynyt suorakylvetyissä ruuduissa kunnolla. Seuraavina vuosina kylvöaika ja -syvyys määritettiin kieritysrajan perusteella: kylvösyvyydessä savimaan kosteuden piti olla sellainen, että maa murustui. Näin toimen kylvösyvyys oli suorakylvössä keskimäärin 1-2 cm matalampi kuin muokatuissa ruuduissa. Kosteusmittaukset tukivat menettelyä: suorakylvetyssä savimaassa oli itämiskosteutta, vaikka siemen kylvettiin muokattua koetekijää matalampaan.

Vuosina 2002-2003 hiuesavimaan kentällä suorakylvetyn koetekijän (B-C) siemensato oli keskimäärin $8-12 \%$ pienempiä kuin syysmuokattujen ja jyrsinkylvettyjen koetekijöiden sadot. Vuonna 2001 liian syvä suorakylvö koetekijän C ruuduilla vaikutti osaltaan tulokseen. Hiesusavimaan kentällä satoerot olivat pieniä vuosina 2001-02. Vuonna 2003 sateet viivästyttivät suorakylvöä kolme viikkoa sänkimuokattuun koetekijään verrattuna. Suorakylvetyn koetekijän sato oli keskimäärin 11 $15 \%$ pienempi kuin syysmuokattujen koetekijöiden sato.

Tähänastisten tulosten perusteella voidaan todetta, että kasvuston perustaminen suorakylväen onnistuu savimaalla. Savimaan pinnan tulee olla riittävän kuivaa suorakylvettäessä, jotta kylvökoneen vantaat murustavat maan siemen yläpuolella haihtumissuojaksi. Satotulokset ovat siirtymäkauden tuloksia. Tarvitaan lisää koevuosia, jotta voidaan arvioida suorakylvön pitkäaikaista vaikutusta viljan viljelyyn. Lisätutkimusta tarvitaan myös eri viljalajien soveltuvuudesta suorakylvöön. 